\title{
Corporate Criminal Liability, Willful Blindness and Lifting the Veil under Nigerian Law
}

\author{
Mohammed Suleh-Yusuf \\ Ph.D. Candidate/Researcher, Nasarawa State University Keffi, Nigeria
}

\begin{abstract}
The essence of this Paper to look beyond the debate on corporate criminal liability in Nigeria which clearly has been exhausted and hinged on established principles of English law and half a century of judicial reviews by English and Nigerian courts. The primary aim is to tread the uncharted path of determining the nature, level and basis of attributing wilful blindness of those considered the company's 'directing minds and will' to the company itself in money laundering and terrorism financing prosecution. Thus the applicability of the alter ego doctrine will lay the intellectual and jurisprudential analysis of the doctrine of wilful blindness as an offshoot of the larger concept of corporate criminal liability in Nigeria. More importantly the Paper will look at the determination of criminal intent of Directors of a company and criminal liability of the company itself.
\end{abstract}

Keywords: Willful Blindness, Alter ego, Respondeat Superior, Directing Mind, Attribution Principles, Mens Rea

\section{APPLICABILITY OF THE DOCTRINE OF ALTER EGO TO THE DETERMINATION OF CORPORATE CRIMINAL LIABILITY IN NIGERIA}

The concept of corporate criminal liability under Nigerian law now has a specific statutory prescription with the advent of Companies and Allied Matters Act (CAMA) in 1990. The foundation of the principle is Section 65(1) (a) of the Act which provides that acts of members of the company in a general meeting or the Board or the managing Director 'shall be treated as the act of the company itself' ${ }^{1}$. The Section went further to state that 'the company shall be criminally andcivilly liable therefore to the same extent as if it were a natural person'. ${ }^{2}$ Section 66 of CAMA also provides that a company shall also be liable for the acts of any of its officers or agents if the company, acting through its members in a general meeting, board of directors, or managing director, expressly or impliedly authorized such officer or agent to act in the form or manner agreed at such meetings.

The provision of the companies statute in Nigeria has not departed from the general influence common law has on the general jurisprudence because it has also adopted several common law principles that set parametres for its prescriptions. For much of the twentieth century, when faced with issues that required action to be imputed to a company as its own the courts turned to the "directing mind and will" test derived from the speech of Viscount Haldane L.C. in Lennard's Carrying Co Ltd v Asiatic Petroleum Co Ltd. ${ }^{3}$, whichwas a civil case. Viscount Haldane's words were subsequently applied in both civil and criminal cases "with no divergence of approach ... the authorities in each being cited indifferently in the other". ${ }^{4}$ As interpreted in some cases, the directing mind and will formula, which also came to be known as the identification doctrine or the alter ego principle, came to denote a metaphysical, abstract conception of the company as a "pulsating entity in action". 5

Lord Hoffmann (or Hoffmann L.J. as he was at the relevant time) ventured into this territory in El-Ajou v Dollar Land Holdings Plc. ${ }^{6}$ El-Ajou was a civil case involving the imputation of knowledge to a company as its own for the purposes of liability in equity for knowing receipt. The Court of Appeal applied the directing mind and will test to assess the status of a Board chairman that is not part of the day to day management of the company and concluded that the acts of the Chairman that resulted in the receipt of misapplied funds remained his personal acts because he acted autonomously and merely committed the company in his own volition. ${ }^{7}$ All three members of the Court of Appeal favoured a relatively flexible interpretation of the directing mind and will

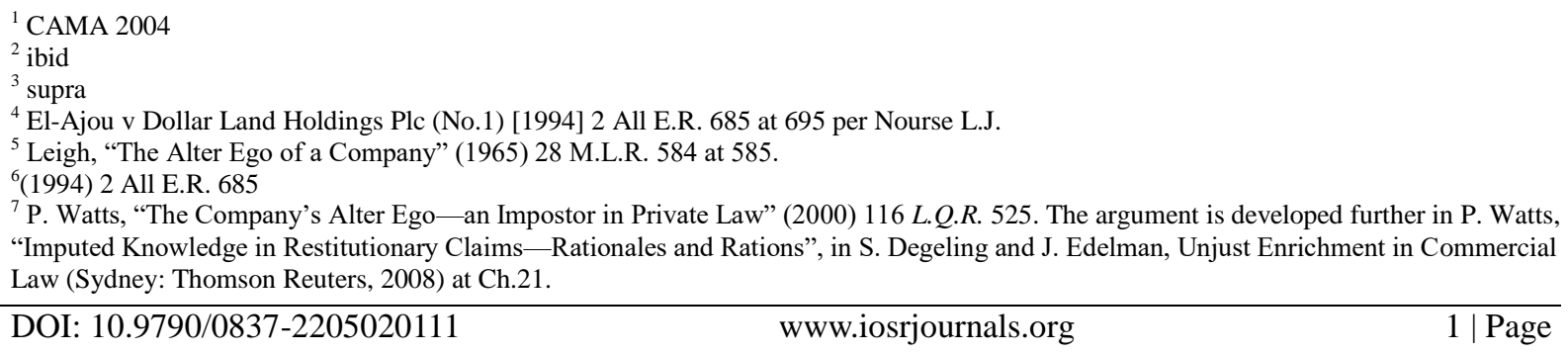

${ }^{7}$ P. Watts, "The Company's Alter Ego — an Impostor in Private Law" (2000) 116 L.Q.R. 525. The argument is developed further in P. Watts, "Imputed Knowledge in Restitutionary Claims-Rationales and Rations", in S. Degeling and J. Edelman, Unjust Enrichment in Commercial Law (Sydney: Thomson Reuters, 2008) at Ch.21. 
test: the natural person or persons who had management and control in relation to the act or omission in point could be regarded as its directing mind and will for that purpose, and therefore a company's directing mind and will might be found in different persons for different activities of the company. This direction of the court of appeal when read together with Hoffmann L.J.'s contention that identification of the directing mind is primarily a constitutional question that depended upon the powers that persons were entrusted to exercise on behalf of the company in its statutes and internal organization. This contention gave a hint as to what was to come later in Meridian ${ }^{8}$ where Lord Hoffman points to where his mind went in his contention. However, there was nothing explicit in El-Ajou to indicate that the directing mind and will test was anything less than an independent attribution principle and based on the circumstances surrounding each situation and case with no general benchmarks.

Lord Hoffmann's approach in Meridian Global Funds Management Asia Ltd v Securities Commission, ${ }^{10}$ a criminal case in which judgment was delivered some 18 months after El-Ajou, was strikingly bolder because the identification doctrine was apparently sidelined in favour of a context-specific and rulesbased analysis that was hinged on the constitutional set up of the company. Lord Hoffmann identified two bases for the attribution of acts and states of minds to a company, over and above the agency principles (or general rules of attribution) that apply both to natural persons and to companies. He highlighted the first rule that primarily guide our review of the constitutional allocation of power and responsibility under articles of association, board resolutions, shareholders' resolutions and other binding shareholders' decisions. The second rule involved fashioning a special rule of attribution for the particular substantive rule. In respect of the special rules of attribution, Lord Hoffmann explained that it is a matter for interpretation and dependent on the language of the Statute, its content and policy. ${ }^{11}$

Lord Hoffmann's views in Meridian were not entirely dissimilar from those of Lord Diplock in Tesco Supermarkets Ltd v Nattrass, ${ }^{12}$ Lord Diplock was skeptical about the use of vivid metaphor in attributing action to a company as its own and he too favoured reference to the articles, board resolutions and shareholders' resolutions to resolve such matters. But applying Lord Hoffmann's analytical framework, Lord Diplock in effect stopped at the primary and general rules of attribution. But the direction of the court in Meridianwas innovative because it outlined reliance on special rules of attribution that can be located in the company's constitutional documents far outside the restrictions of job titles or customary roles of managers or directors. There is a need for a careful reading of Re Supply of Ready Mixed Concrete (No.2,), ${ }^{13}$ a case on corporate liability for contempt arising from acts done by employees within the scope of their employment decided around six months before judgment in Meridian, in which Lord Nolan had pointed out that Tesco Supermarkets had turned on construction of a particular statute and sets an irresistible precedence. In Lord Nolan's admonition he also aligned with the Meridian case because it has escaped the restrictive ceiling created by the court in the Tesco's case; in his view we must shy away from the irresistible temptation set in Tesco's case to attribute acts to companies based on categories of persons involved rather he suggested leaning on the company's constitutional rules and powers.

What of the directing mind and will test? According to Lord Hoffmann in Meridian it was just a phrase that Viscount Haldane had used in the context of interpreting the particular statute in question. His Lordship accepted the usefulness of the phrase-"'It will often be the most appropriate description of the person designated by the relevant attribution rule" ${ }^{14}$ - but determined that not every substantive rule had to be forced into the same formula because the question was one of construction rather than metaphysics. What of cases such as El-Ajou that had, seemingly, elevated the test to doctrinal status? ${ }^{15}$ In Lebon v Aqua Salt Co Ltd ${ }^{16}$ Lord Hoffmann, again delivering judgment for the Privy Council, explained away El-Ajou as an earlier example of the principles articulated in Meridian.

In Nigeria the courts have also followed the judicial footpath of the English courts with reliance on the alter ego principle to attribute acts of senior officers, managers and directors of the company to the company itself. In Aderemi $\mathrm{v}$ Lan and Baker Nigeria Ltd, ${ }^{17}$ Aderemi JCA stated that by recognizing the separate personality of the company the law has drawn a veil of incorporation and he opined that it is now settled law

\footnotetext{
${ }^{8}$ supra

${ }^{9}$ ibid

${ }^{10} \mathrm{ibid}$

${ }^{11}$ Meridian Global Funds Management Asia Ltd v Securities Commission [1995] 2 A.C. 500 at 507.

${ }^{12}$ (1909) 21 U.S 481

${ }^{13}$ Re Supply of Ready Mixed Concrete (No.2) [1995] 1 A.C. 456 at 474.HL

${ }^{14}$ Meridien supra

${ }^{15}$ P. Watts, "Auditors and Corrupt Clients" (2009) 125 L.Q.R. 38 at 41 (suggesting that the reasoning in El-Ajou needed to be reconsidered in the light of Meridian).

${ }^{16} 36$ (2009) UKPC 2; [2009] B.C.C. 425 PC (Mauritius).

${ }^{17}$ (2000)7 NWLR Pt 663 at 51 
that the directors or managers are those whose decisions can be attributed to the legal fiction ${ }^{18}$. He concluded that 'there is nothing sacrosanct about the veil of incorporation'. ${ }^{19}$

He went further to assert that the court must be ready and willing to open the veil of incorporation to see the character behind it, if justice must be seen to be done. In another Nigerian decision the court in PFS Ltd $\mathrm{v} \mathrm{Jefia}^{20}$ found constructive fraud in the acts of the chairman and managing director of the company and held that the case falls under Section 290 of CAMA ${ }^{21}$ and Rowland JCA observed that it is trite law that in certain instances the court can lift the veil and find out who was behind a fraudulent or improper conduct. This will be necessary where the canopy of legal personality is used to defeat public convenience, justify wrongdoings and perpetrate fraud. Similarly in Nigerite Ltd v Dalami (Nigeria) $\operatorname{Ltd}^{22}$ the court held that while a company which is duly incorporated cannot be disregarded on the ground that it is a sham, then it may be established by evidence that in its operations it does not act for itself as an independent entity but 'simply for and on behalf of the people by whom it has been called into existence'. ${ }^{23}$ Furthermore in Orji v Onyaso ${ }^{24}$ and Nigerian National Supply Ltd v Hamajoda Sabana Co. $\operatorname{Ltd}^{25}$ the courts provided further clarity on the alter ego principle in Nigeria; the courts were of the opinion that those whose acts will bind the company in the absence of any specific authorization qualify as the alter ego; because of their position as directing minds and will of the company. Thus they represent the very ego of the company. In fact Tsammani JCA in another case ${ }^{26}$ was of the view that that the doctrine clarification on the demarcation between shareholders and the corporate personality is the backbone of the alter ego principle in Nigeria.

It is encouraging to note that the alter ego principle has been established in Nigeria with no vague outlines and the courts have started taking that direction in determination of corporate criminal liability as well as the extent of the veil that can be lifted through the judicial process. Though there are still rough edges it is clear that this principle provides adequate ammunition to guide law makers and jurists in Nigeria. Thus there are still areas of uncertainty particularly in relation to whether the Nigerian courts should rely on 'strict attribution principles' as set in the Tesco's case or rather deep dive into corporate constitutional documents to determine the allocation of responsibilities, liabilities and status of the natural persons as recommended in the Meridian case. In determining whether acts of an alter ego can be attributed to a company in relation to wilful blindness it will be restrictive to either apply the 'narrow' direction of the decision in Tesco or the 'expanded' parameter of the Meridian decision because of the subjective nature of this angle of corporate criminal liability. The ideal approach is to seek a different approach that marries the documented distribution of corporate powers as well as the practicality of corporate practice in Nigeria.

The attribution principles have developed in such a way that it leaves open the determination of who qualifies as an 'alter ego' to pragmatic evaluation on case-by-case basis; ironically it also has the added benefit of insulating the company from certain acts of those that may have qualified as alter egos but will be wrapped alone in their personal liabilities. In Federal Republic of Nigeria v Nwoche Odogwu and Capital Merchant $\mathrm{Bank}^{27}$ the promoter of the Bank who also doubled as its Managing Director was accused of granting unsecured loans that were later diverted for his personal use. The Court sentenced the Managing Director to 18 years in prison but discharged the Bank because it could not attribute the intents and acts of the Managing Director to the Company itself. The attribution principles are not just tailored to allocate criminal liability to companies or share them amongst the company and its alter egos; but it is also an instrument to protect the company from unscrupulous alter egos that can expose it to liabilities.

\section{DETERMINATION OF CRIMINAL INTENT OF COMPANIES UNDER NIGERIAN}

\section{LAW}

Criminal law has been forced to develop a series of responses to the problem of corporate mensrea to effectively achieve 'the goals of punishment, retribution, and deterrence' ${ }^{28}$ Although companies generally do not have the nature or qualities of human beings, criminal law has metamorphosed to a level where companies are being held to the same culpability standards as natural persons.Furthermore where there are serious infractions by companies and there are no visible signs of any culpability by its officers or directors some courts have been pushed into aggregating corporate agents' actions and states of mind and impute them to the

\begin{tabular}{l}
\hline${ }^{18}$ ibid \\
${ }^{19}$ ibid \\
${ }^{20}$ (1998) 3 NWLR Pt 543 at 602 \\
${ }^{21}$ Chap20 LFN 2004 \\
${ }^{22}$ (1992) 7 NWLR Pt 253 at 288 \\
${ }^{23}$ supra \\
${ }^{24}$ (2000) 2 NWLR Pt 643 at 19 \\
${ }^{25}$ (1988) 2NWLR Pt 74 at 23 \\
${ }^{26}$ (CA/PH/300/2007) \\
${ }^{27}$ (1997) 1 F.B.T.L.R 179 \\
${ }^{28}$ Pamela H. Bucy, "Why Punish?, Trends in Corporate Criminal Prosecutions"(1988)44 Am. CRIM. L. REV. 1287,
\end{tabular}

DOI: 10.9790/0837-2205020111 www.iosrjournals.org 3 Page


company. ${ }^{29}$ But some critics caution that the collective knowledge doctrine is potentially dangerous in scope, and that the definition of corporate collective knowledge is not necessarily synonymous with the definition of collective criminal intent. With this concern in mind, some scholars have opined that the best way to apply the collective knowledge doctrine is "in conjunction with other considerations that may more accurately point to culpability, most notably the presence of willful blindness. ${ }^{30}$ Thus where the officers or directors of the company act in 'wilful ignorance' to avoid personal liability the courts must unwrap the cloak to share the culpability adequately amongst all the participants. This is the meeting point where corporate criminal liability overlaps into consideration of 'wilful blindness' as an active state of mind that can be attributed to the alter ego of the company.

In the UK the courts have gradually evolved basis for measuring and determining the corporate mens rea by using different methods. The English courts had used the civil law doctrine of vicarious liability by holding a company liable for the mens rea of its officers. This gradual evolution can be deducted from the case of Mousell Brothers Ltd v London and North -Western Railway Company, ${ }^{31}$ where it was held that a company could be vicariously liable for the acts of its employees and face the consequences associated with these acts. The Court was clear that a corporate body is vicariously liable for acts done by or on instruction or through implied or express permission of its directors or servants. However, the vicarious liability method the Court relied on in this case does not accurately capture the corporate mens rea or properly determine the extent of the company's liability. This is because it is against the individualistic notion of the criminal law to hold a "person" liable for the wrong of another person and this reduces the efficacy of this civil law action in meeting the retributive character of criminal law. Secondly, the attribution of the actions of an individual to a company through vicarious liability seems to render the issue of mens rea irrelevant and clearly that washes away one of the central cornerstones of criminal obligation and responsibility. This is because applying vicarious liability to corporate criminal liability renders a company guilty irrespective of the fact that it had not the mens rea to commit the act constituting the offence or even of the fact that the act itself might have been committed contrary to its corporate policy. This 'weakness' of this tortious liability has left open the need to develop corporate criminal liability as a tool of determining both the intents and acts of individuals that can be attributed to the company to meet the most basic requirements of criminal law principles.

Extension of criminal liability to cases requiring intent took a while longer in the UK. According to Wells ${ }^{32}$, the doctrine of precedents contributed to this as it hampered courts from applying corporate criminal liability even after the initial procedural difficulties had been removed. However, in 1944, three cases decided within months of each other paved the way for corporate criminal liability in cases requiring intent. While the reasons why these decisions so close to each other were made at this particular time is uncertain, the effect has been said to be revolutionary ${ }^{33}$. In all three cases ${ }^{34}$, the courts indicted a company for an offence requiring intent to deceive, conspiracy to defraud and using a document with intent to defraud respectively. The courts were able to do so by attributing the intent of its officers to the company itself, so that the officers were acting as the company and not/or the company. It was therefore the company itself which was liable and not merely being liable for the acts of its officers as under the vicarious liability doctrine. In Nigeria the courts have taken the same direction as the English courts in determining criminal intent of companies in their prosecution for crimes. Likewise the concept has gone through the same evolutionary stages including the transition through vicarious responsibility before the current reliance on criminal law principles to prosecute companies.

In DPP v Kent and Sussex Contractors, ${ }^{35}$ Viscount Caldecott, after reviewing a long line of cases, concluded, that "(T]he officers are the company for this purpose ... There was ample evidence on the facts ... that the company, by the only people who could act or speak or think for it had done both these things." ${ }^{36}$ While this was not expressly stated in any of the three cases, the attribution of the intent of the officers of the company to the company itself emerged in the law of torts and the courts may have been influenced by the reasoning of the court in the earlier case of Lennard's Carrying Co. v Asiatic Petroleum. ${ }^{37}$

Some recent cases such as Attorney General s Reference (No.2 of 1999$)^{38}$ and Rowley v DPP, ${ }^{39}$ have also given restrictive interpretations to determination parametres of the type of persons whose mens rea and actus Reus reflects not just that of the company but mirror its internal corporate behaviour. This clearly is the

\footnotetext{
${ }^{29}$ Patricia S. Abril \& Ann Morales Olazbal, "The Locus of Corporate Scienter",(2006) COLuM. Bus. L. REV. 81,

${ }^{30}$ Eli Lederman, "Models for Imposing Corporate Criminal Liability: From Adaptation and Imitation Toward Aggregation and the Search for Self-Identity" (2000) 4 BuFF. CRIm. L. REV. 641, 666

${ }^{31}$ (1917) 2 K.B 836

${ }^{32}$ Professor Celia Wells is a foremost scholar on corporate criminal liability

${ }^{33}$ R.S welsh , "The Criminal Liability of Corporations" (1946) 62 Law Q. Rev 346

${ }^{34}$ DPP v Kent and Sussex Contractors; R v ICR Haulage and Moore v Bresler

${ }^{35}$ supra

${ }^{36}$ This has variously been called the identification or alter ego doctrine or theory.

${ }^{37}$ supra

38 (2000) 2 cr app R 207

39 (2003) EWHC 693 
one most important factor that reduces the efficacy of the identification doctrine in attributing corporate criminal liability. First, there are no clear criteria for determination of persons whose mens rea could be attributed to the company for purposes of criminal liability. Although the House of Lord's decision in Tesco v Nattrass ${ }^{40}$ gives a restrictive interpretation by limiting these individuals who sit atop the management pyramid but it changed this direction in the case of H.L. Bolton (Engineering) Co. Ltd, ${ }^{41}$ where the Court recognized managers of the company who were in charge of the daily running of the company as being persons whose mental state can be attributed to the company without determining their position on the corporate pyramid. Secondly, even without such divergence and lack of clarity, this restrictive interpretation of the doctrine greatly reduces the chances of successfully attributing liability to the company as it poses the rather difficult problem of finding a responsible officer high enough in the corporate hierarchy whose actus reus coincides with the requisite mens rea to be attributed to the company. This is more glaring because modern companies are more complex and have layers of corporate structures that are not in line with the traditional corporate pyramid envisaged by the Court in the Tesco's case. In such complex modern companies, the mens rea of a lowly manager, who in reality is in charge of the day to day decisions for the running of the company, may not be considered a controlling mind of the company in light of the Tesco ${ }^{42}$ decision and will leave the determination open to uncertainties and contextual restrictions.

The identification method has also been used to determine the corporate mens rea in the UK and clearly this has also impacted the direction of the Nigerian jurisdiction. The identification method was introduced into criminal law by the English courts in a series of cases that were decided in 1940s. This method locates the mens rea of the company in a natural person who is the directing mind of the corporation and has control over its levers of operation. There is no better illustration of this approach of the English courts than the case of D.P.P v. Kent, ${ }^{43}$ where it was held that a company can only have knowledge through its human agents and where any of its agents acts within the scope of his authority; his knowledge and intention has to be imputed to the company. In the subsequent case of Bolton (Engineering) Co. Ltd. v. Graham and Sons, ${ }^{44}$ Lord DenningLJ stated that 'a company may in many ways be likened to a human body. It has a brain and nerve centre which controls what it does. It also has hands which hold the tools and act in accordance with directions from the centre'. Therefore in Lord Denning's conclusion some of the people are mere agents or servants while the others are 'directors and managers who represent the directing mind and will of the company, and control what it does...' This means there is a need to identify those that qualify as 'directing minds' before attributing their mens rea to the company.

In the United States the principle of respondeat superior has also been used to justify holding a company liable for the mens rea of its officers or agents. It was clear that the United States Supreme Court in the New York Central ${ }^{45}$ case was viewing the attribution of intents and acts of officers and directors to the company because it holds the opinion that the fictional nature of corporate personality means the company can only act through its officers and agents. It also was of the opinion that for these acts to be attributable to the company, three key factors must exist. The first factor is that there must be the commission of a crime by a natural person that acts as an agent or employee of the company. Secondly, the identified crime must have been committed in the course of employment and within the scope of the natural persons' engagement. Lastly, such crime must have been done with the intent to benefit the company. In applying its conclusion on the attribution of acts of natural persons to the company relying on the doctrine of respondeat superior, the court considered both the apparent and express authority of the employee to have acted in that manner that exposed the company to criminal liability. Though it is noteworthy that it is not in all cases that United States Courts work with the notion that an officer or agent of the company must have acted within the scope of his engagement or the express instruction of the company before his acts can be attributed to the company under the rules of the doctrine of respondeat superior. In United States v. Hilton Hotels Corporation, ${ }^{46}$ Hilton hotel was held liable despite a glaring evidence that the responsible employee acted contrary to the hotel's instructions. The court further concluded that a company can be held liable even if it had in fact received no benefit from the crime committed so long as the employee intended to benefit the corporation. Thus the attribution principles laid out in New York Central are not iron clad preconditions before acts of natural persons can impose criminal liability on a company.

There is no gainsaying that in Nigeria the courts have relied on the alter ego principle to see behind the corporate veil in determining both corporate intent and culpability; this has pushed the legal system to rely on decisions of English courts and jurists. It is an important legacy of colonialism that the Nigerian legal system

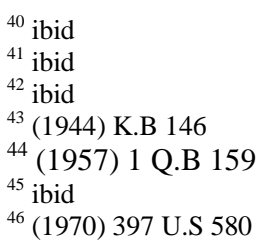


has its foundation in the English common law; this influence is quite far reaching in outlying the parametres of corporate criminal liability. It is therefore not surprising that many decisions in Nigerian courts have cited remarkable decisions such as that of the House of Lords in R v Kent and Sussex ${ }^{47}$ and the setting of the qualification of 'directing mind and will' in Leanard's Carrying ${ }^{48}$. These decisions provided the Nigerian courts with the manure that fertilized the approach and conclusions on corporate criminal liability.

In Nigeria the courts have often made reference to the common law terms of mens rea and actus reus in assessing corporate criminal liability in Nigeria. A good example is the case of Abeke v State, ${ }^{49}$ where it was held that mens rea means a guilty mind and is a necessary precondition for attributing criminal acts to either a natural person or a fictional personality. This has also been captured under statutory law in the country and a good illustration is in Chapter five of the Criminal Code which deals with criminal responsibility and it provides in Section 24 thus:

"Subject to the express provisions of this code relating to negligent acts and omissions, a person is not criminally liable for an act or omission, which occurs independently of the exercise of his will, or for an event which occurs by accident. Unless, the intention to cause a particular result is expressly declared to be an element of the offence constituted, in whole or part, by an act or omission, the result intended to be caused by an act or omission is immaterial.

Unless otherwise expressly declared, the motive by which a person is induced to do or omit to do an act, or to form an intention, is immaterial so far as regards criminal responsibility."

The above Section explains criminal responsibility under the Code. First, the physical element is recognized to be in the form of an act or omission. Secondly, the requirement for the mental element is explained in three ways as follows. The first paragraph means that there can be no liability without fault. The word "will" in the paragraph means the accused's intention and awareness of the circumstances connected to the act. The second paragraph provides for result offences and simply denotes the common law rule on presumption of mens rea that unless intention is expressly stated as part of the definition of an offence, it is immaterial that the accused intended to cause a different result. Also, the wordings of Section 24 show a presumption against vicarious liability for a mental element; it states that a person is said not to be liable for an act which occurs without the exercise of his will. This is clearly meeting the expectations of personal liability, which remains a major cornerstone of criminal responsibility. Therefore, from these provisions, the mens rea or mental element is acknowledged; it is a matter of semantics that the common law phrase is not used expressly in the Code.

Under the Penal Code that is applicable in Northern part of Nigeria, the words mens rea and actus reus are also not clearly expressed or pointed out. The Penal Code provides in Chapter Two for criminal responsibility and its provisions also show that the common law principle of no liability without fault was used as a guiding principle. Therefore established common law mental state benchmarks such as 'intention', 'knowledge', 'fraudulently' and 'dishonestly' are used to define the mental element in the determination of offences under the Penal Code. Section 48 of the Code provides: "Nothing is an offence which is done by accident or misfortune and without any criminal intent or knowledge in the course of doing a lawful act in a lawful manner by lawful means and with proper care and caution". ${ }^{51}$ The most natural understanding of the phrase "proper care and caution" will infer acts done without negligence. Intention, knowledge and negligence are used in the above provision of the Penal Code to infer the necessity of the mental element as a premise of determining guilt and distribution of liability. In that vein Section 51 also provides that: "Nothing is an offence which is done by a person who, at the time of doing it, by reason of unsound mind, is incapable of knowing the nature of the act, or that he is either wrong or contrary to law." This tallies with our earlier conclusion on the reliance of the common law principle that places liability only to where a fault is placed. Therefore, although the terms actus reas and mens rea are not expressly used in both the Criminal and Penal Codes, however, both legislations recognize that there must be a physical and mental element to criminal liability.

Beyond the Criminal Code and Penal Code, there are other enacted statutes that have made provisions for corporate criminal liability in Nigeria and have also made provisions for determination of the attribution principles. But a good view of the applicability of the Criminal Code can be located in the case of R v Zik Press $^{52}$ where a company was found guilty of an offence of contravening Section 51(1) (c) of the Nigeria's Criminal Code. A second example can be seen from the outcome of the case of Mandilas \& Karaberis v. COP ${ }^{53}$ where another company was convicted of the offence of stealing by conversion under sections 390 and 383 of the Nigerian Criminal Code. While in A.G Eastern Region v Amalgamated Press of Nigeria Ltd ${ }^{54}$ the

\footnotetext{
47 supra

48 supra

49 (2007) 3 S.C Pt11, 105

${ }^{50}$ LFN 2004 Chap 77

${ }^{51}$ LFN Chap 892004

52 (1947) 12 W.A..C.A 202

53 (1958) 3 F.S.C 20

54 (1961) 1 All N.L.R 199
} 
preliminary objection raised by the defendant on the ground that an offence could not be committed by a company in the absence of men rea was overruled by the court; which relied on the attribution principles to determine the liability of the company based on the intents and acts of its officers and directors. However, the court was clear that certain offences cannot be attributed to the company and cited offences of personal violence or with offences for which the only punishment is imprisonment. Nevertheless, the cases of $\mathrm{R} v$ Corry Bros $;{ }^{55}$ Granite Construction Company v Superior Court ${ }^{56}$ and Northern Mining Construction Company Ltd v Glamorgan Assizes ${ }^{57}$ have all established the fact that companies could be held liable for manslaughter. The position in Nigeria is better understood from the perspective of Erhaze and Momodu who stated that "the notion of corporate criminal liability being a recent development, cases are rare and there are yet no known cases of corporations being charged for the offences of manslaughter or murder". ${ }^{58}$ They went further to state that Nigeria being a former colony of the United Kingdom has relied on the principles of corporate criminal liability under the old common law doctrine "that relies on the attribution principles that is restrictive when offences are of such nature that only natural persons can commit them" ${ }^{59}$ They also were of the opinion that the common law has set the basis for determining corporate criminal liability based on the 'identification doctrine', "which requires that intents and acts of officers and directors of a company are attributed to the company". ${ }^{60}$

The reference above to the two core statutes outlining criminal responsibility in Nigeria is to lay the foundation for our dissection of the provisions of the focal laws determining criminal responsibility for money laundering and terrorism financing. The Money Laundering Prohibition $\mathrm{Act}^{61}$ has made provisions for corporate criminal liability alongside that of natural persons; a good example is Section 1 that made separate provisions for natural persons and companies with different parameters. Infact in Section 19 it made clear provisions for offences solely committed by companies with punishments that include winding up and forfeiture of assets. Likewise the Act made some specific provisions for directors and establish a separate line of liability in Section 12. The same approach was adopted by the Terrorism Prevention $\mathrm{Act}^{62}$ and to highlight this further is to concentrate on Section 25 that made clear provisions on companies where it stated that 'Where an entity is convicted of an offence under this Act, it is liable to the forfeiture of any assets, funds or property used or intended to be used in the commission of the offence and the court may issue an order to windup the entity'. It also made clear provisions for directors and officers of the company where it stated that 'Where an offence under this Act committed by an entity is proved to have been committed on the instigation or with the connivance of, or is attributable to any neglect on the part of a director, manager, secretary of the entity or any person purported to act in any such capacity, the officer is liable on conviction to life imprisonment'.

There is no doubt that under both statutory and case law in Nigeria criminal intent of companies has been established and hinged on the direction set by the English Common law through the attribution principles. Hence this will also guide the location of the point of intent of companies where the basis of the prosecution is an act of wilful blindness of the company. The simple deduction is to lay the point of determination to the root base of the attribution model that guides on identification of the alter ego and in this instance to also review the acts of such alter egos in relation to the principles set out in wilful blindness. The essence of this Paper is to analyze an uncharted course in this area of the law as the current focus of corporate criminal liability in Nigeria is still fixated on the larger attribution parameter for 'controlling minds and will' rather than the more complex analysis of the applicability of the alter ego approach to determining wilful blindness in money laundering and terrorism financing prosecution of Nigerian companies. Hence this Paper will dwell on three main points; first who can be considered an alter ego when determining wilful blindness of a Nigerian company in money laundering and terrorism financing prosecution; secondly when will such acts be considered 'wilful blindness' in determining corporate criminal liability and lastly to highlight areas where the law has left open areas for uncertainties and possible mitigation of such risks to companies.

\section{LIABILITY OF DIRECTORS UNDER NIGERIAN COMPANY LAW AND THE CONCEPT OF LIFTING THE VEIL}

There has been an unending argument about the nature, extent and level of liabilities of company directors under Nigerian law; this is further compounded by the veil of incorporation that seems to provide protection to directors and shields them from culpability for criminal acts. The Companies and Allied Matters

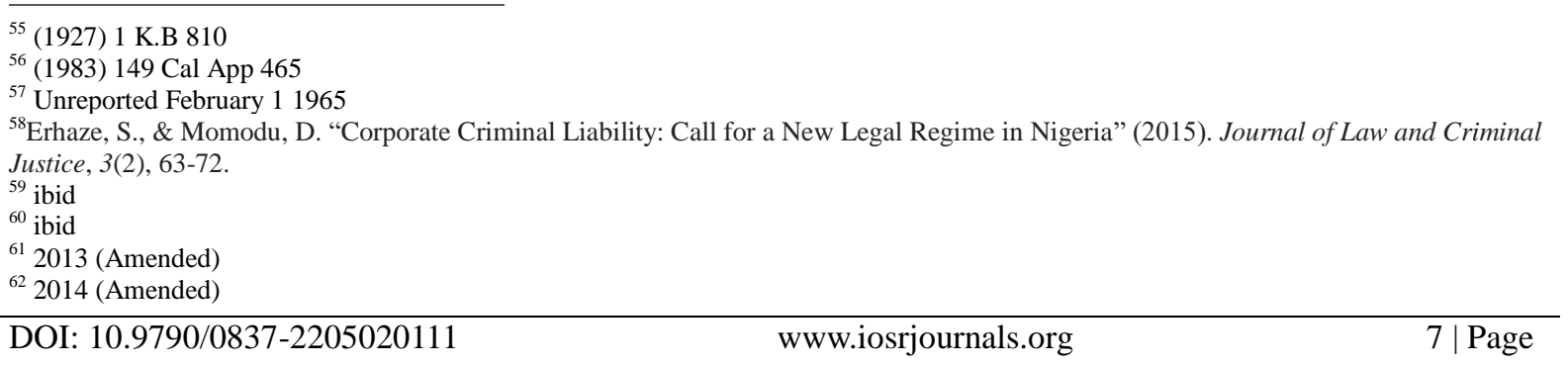


Act in Nigeria was clear that any person appointed by a company to direct or manage its business ${ }^{63}$ qualifies as a director or even those described by the company as its directors, whether in executive roles or otherwise ${ }^{64}$ This is possible because the Act has also codified the Common Law principle of legal personality outlined in Solomon v Solomon Ltd; ${ }^{65}$ Section 37 CAMA separates the directors from the juristic personality of the company. Hence in certain instances the veil of incorporation of the company can be lifted or pierced to see the personal liabilities of its directors as against that of the company. There is a still concerns that some directors hide behind the corporate veil to perpetrate criminal acts and assume the protective cover that the companies provide; more so companies have also benefitted from these acts and seem hesitant to disown these directors.

In Kurubo v Zech-Motison Nigeria Limited, ${ }^{66}$ Tobi JCA (as he then was) was of the view that the liability of a company is dependent on the action of its human drivers and such natural persons will incur liabilities on its behalf. This view of Tobi JCA was clarified by Section 250 CAMA which states that a person not duly appointed as a director cannot transfer the burden of such acts to the company and must bear the responsibility; this clearly means that not all acts of persons associated with a company can be ascribed to it. Infact a clearer view was espoused by Pinto and Evans; they succinctly stated:

"in criminal law there is no parasitic liability of directors, so a director is not guilty of an offence simply because the corporation itself is guilty, a condition precedent to conviction of a director is some act (or omission) on his or her part. Where a director has acted criminally, it is no defence that he did so within the scope of his employment and was committing the crime on behalf of his employer" ${ }^{\prime 67}$

Therefore a director cannot escape liability even where he has acted for and on behalf of the company; rather he will be personally liable and the company could also be liable under the principles of alter ego. There are also instances where the law clearly placed the criminal liability on the directors excluding the company itself; a good illustration is Section 369 CAMA which criminalizes false information provided to auditors by an officer or director of the company.

In the UK the courts have been quite active in looking behind the curtain of incorporation over the years and have not hesitated to lift that curtain where necessary. In Re Darby, ${ }^{68}, \mathrm{R} v$ Bugle PressLtd ${ }^{69}$ and Gilford Motors Co. Ltd v Horne ${ }^{70}$ the English courts have lifted the veil of incorporation and reviewed conducts that are naturally covered by the legally personality of the company. A clearer instance is the case of Littlewoods Stores Ltd v I.B.C ${ }^{71}$ where Lord Denning MR captured the attitude and direction of English courts to lifting the veil of incorporation. He stated that:

'The doctrine laid down in Solomon's case has to be watched very carefully. It has been supposed to cast a veil over the personality of a limited; liability company through which the court cannot see. But that is not true. The court can and often do, draw aside the curtain. They can and often do pull down the mask. They look to see what really lies behind"

In Stone Rolls Ltd v Moore Stephens ${ }^{72}$ the House of Lords threw more light on corporate personality and lifting the veil, the Court was clear that where the company owner uses the company as a device to commit fraud the company can in turn be his alter ego and not the other way round. The Courts have a different view on lifting the veil for criminal matters from the dominant position on lifting the veil for civil matters. In Adeniji v The State ${ }^{73}$ the Court at the first instance agreed that the veil should be lifted to see the person behind the company in a case of fraudulent collection of premium on a non-existent insurance. On appeal Sulu-Gambari JCA observed that 'rendering the sole proprietor criminally responsible amount to application of an equitable' solution. He further observed that while the acts of an individual could be taken as the act of the company it can be expedient in certain circumstances to see behind the veil. But NikiTobi JCA (as he then was) preached caution ${ }^{74}$ and stated that it will be 'absurd and dangerous to make an individual criminally responsible for acts done for and on behalf of the company' without an express statutory provision making him liable.

More so where the court is satisfied that the company is a "mere façade" ${ }^{75}$ concealing its true nature or the actual intentions of its promoters the court must lift the veil. Though it is still unclear how the court will determine whether a company is a 'mere façade'; the court must review the motive of the promoters and the nature of the acts carried out by the company. Clearly to achieve this the court must lift the veil and search into

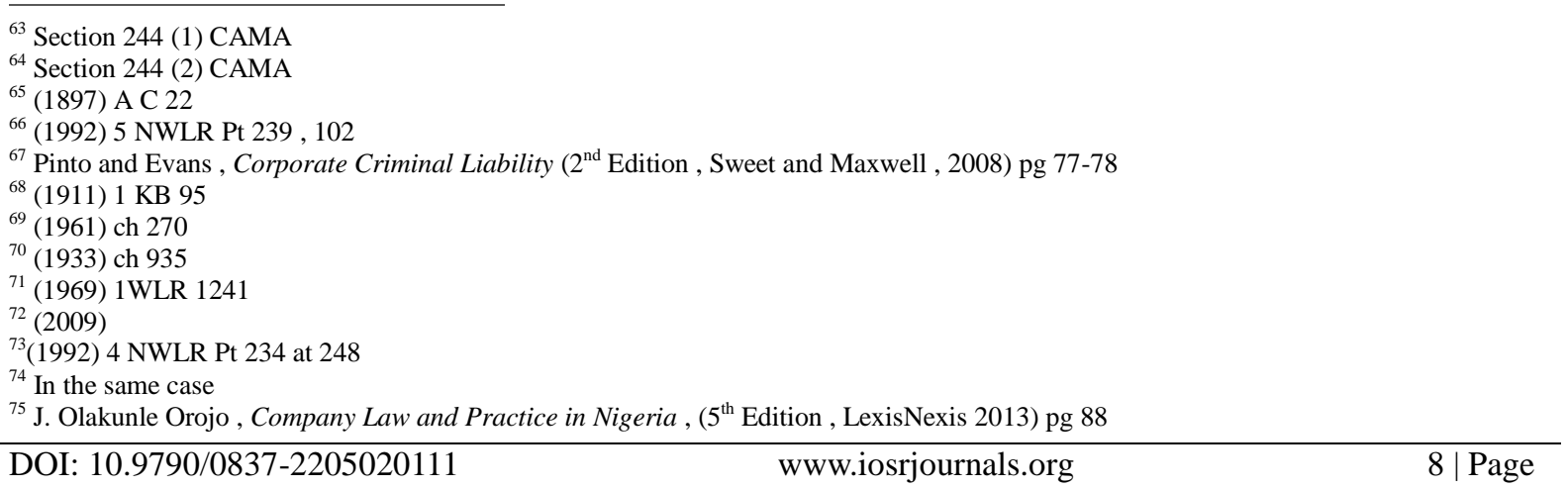


the inner sanctum of the company. In Mezu v Cooperative and Commerce Bank ${ }^{76}$ the Court held that due to discrepancies in a deposition made by the Plaintiff in relation to whether he owned a property or his company; the court must lift the veil to confirm ownership. This is further cemented when we look at the court's mindset in NBCI v Integrated Gas Nigeria limited ${ }^{77}$ where the Court reiterated the need to distinguish between the corporate entity of the company and its biological members by drawing a veil that ought not to be lifted except there is a justifiable cause to do so. In Brundred v Rice, ${ }^{78}$ promoters of a company organized a separate entity for the purpose of consummating an illegal railway rebate agreement thinking it will shield them from liability. The Court held that 'the act of incorporating can be of no avail to them as a defence' and the Court in penetrating the sham rightly concluded that there was nothing 'sacred in a certificate of incorporation' that will protect them from criminal liability. A further illustration can be found in Donovan v Purtell, ${ }^{79}$ where an unscrupulous real estate operator organized a number of different realty companies, all of which had the offices in the same room with same officers; with the main purpose to evade judgment on assets by transferring them round these sham companies. The Court held that all the companies were only façade for the operator and cannot provide him the benefit of distinct personalities.

In Public Finance Securities Limited v Jefia ${ }^{80}$ the court provided instances when the veil can be lifted; one of which is to find out who was behind the fraudulent and improper conducts of the company. The court stated that this is necessary where the canopy of legal entity is used to defeat public convenience, justifying wrong, perpetrate fraud and crime or the company is suspected of involvement in reckless and fraudulent trading activities. However the veil cannot be lifted for the purpose of attacking legal responsibility or liability to its officers who are carrying on the usual business of the company, this was made clear by a court in Chartered Brains Limited v Intercity Bank $\mathrm{Plc}^{81}$ in Nigeria. It is clear that Officers and directors of a company have unique positions in the affairs of the company and courts naturally impute their actions and omissions to that company, because they embody the company itself. Yet in some jurisdictions, such as the United States the court looks at the status of the culpable director before imputing his acts to the company; in United States v Empire Packing Company ${ }^{82}$ the court considered the President of the company senior enough to embody the intent of the company when he instructed various low level employees to collect kickbacks from prospective purchasers. Another court ${ }^{83}$ in that jurisdiction made a similar conclusion while determining the company's liability in unlawful payments made to union officials by highly placed company executives. In United States vRichmond ${ }^{84}$ the United States Supreme Court held a company liable for a number of falsified invoices submitted by one of its officers in connection with public construction projects.

It should be noted that in Nigeria a director of an incorporated company may be personally liable where the company carries on business for six months without having at least two members; ${ }^{85}$ or carries on business without at least two directors for a period of sixty days. ${ }^{86}$ The statute also provided other areas where such liability rests on the director to include an instance where the company carries on business for more than six months after the membership has fallen below two; every director or officer of the company who continues to carry on the business will be jointly and severally liable for all debts incurred by the company during the period. ${ }^{87}$ Therefore there are situations where liabilities are transferred to directors statutorily as contained in the cited provisions of CAMA in Nigeria. The company statute though made a clear attribution of the acts of the members that were based on the general meeting and set out functions; these acts will then be ascribed to the company. Clearly Section 65 of CAMA has made provisions for transferring liabilities of human agents to the company itself; yet that still leaves open the question of who qualifies as the director or officer of the company? Section 650 of CAMA defined who an officer of the company is and some court decisions have made it clear the qualification to act on behalf of a company. In Ekuma v Silver Eagle Shipping Agencies Ltd ${ }^{88}$ the court was emphatic that the secretary of a director does not qualify to represent the mind of the company and in Nigerian National Supply Ltd v Alhaji Sabana and Sons Ltd ${ }^{89}$ the court angrily concluded that a receptionist cannot be an alter ego of a company and it held that it is not the acts of every servant that binds the company.

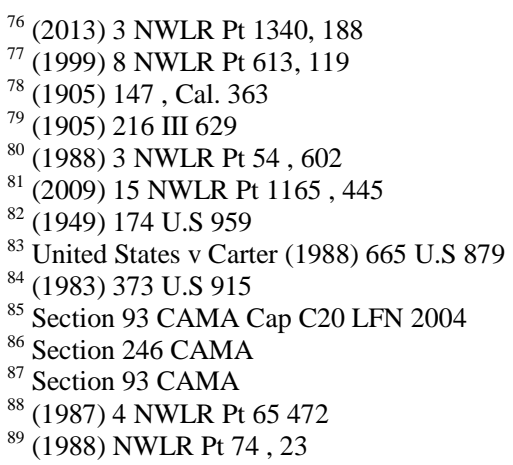


The above position tallies with the understanding of Lord Parker in Daimler Co. Ltd v Continental Tyre and Rubber Co. Ltd $^{90}$ where he stated that acts of organs of a company, its directors, its managers, its secretary and other officers will remain the acts of the company if they are within scope of their authority. A more expansive view was provided by Jesse MR about forty years before Lord Parker made those conclusions. Jesse MR in Re Forest of Dean Coal Mining Co. ${ }^{91}$ was of the view that though directors have been classified as trustees or managers of the business of the company; the end review is that a director's true position and status is that of commercial men managing a business for the benefit of themselves and all other subscribers. Therefore in his conclusion the director's acts are those of the company with little or no demarcation.

In Nigeria case law has demarcated the liabilities of directors and the companies they represent by pinpointing types of engagements of directors that either bind the director or the company he represents. In Yesufu v Krupper International N.V the Supreme Court ${ }^{92}$ held the opinion that where a director contracts expressly or impliedly on behalf of the company he represents, the company will be responsible for the obligation he creates. The Court was also emphatic that the director will only assume personal liability if he made a commitment that bestows personal liability on him. But it is also necessary to review the opinion of the apex court against the court just below it in hierarchy. The Court of Appeal in Kurubo v Zach Mottison Nigeria Limited $^{93}$ made some conclusions that further explained the direction of the Supreme Court was to take three years later in Yesufu v Krupper International. Tobi JCA (as he then was) was of the opinion that the company being an 'artificial person' clearly lacks the 'natural or physical capacity to function' and hence as of necessity, rather than convenience, must rely on natural persons to negotiate and contract on its behalf. Though it is pertinent to note that both the Supreme Court and the Court of Appeal had their gaze fixated on contracts and civil law remedies when getting to these conclusions. The direction of Nigeria on criminal liability of directors is also aligned to the mindset built through the years on issues of contracts and obligations. In Macebuh $\mathrm{v}$ National Deposit Insurance Corporation ${ }^{94}$ the Court opined that the corporate veil can be lifted when dissecting criminal liabilities of companies. Akinola Bukola ${ }^{95}$ also conducted a critical appraisal of the doctrine of corporate personality under Nigerian company law and made the same conclusions on the lifting of the corporate veil on issues of criminal liability and determination of intents and acts of natural persons behind the corporate wrongdoing. Bukola's view also echoes that of C.S Ola ${ }^{96}$ who was of the opinion that while apportioning criminal responsibilities in acts committed by a company there can be no restrictions based on the cloak of the corporate veil. Therefore there are statutory and judicial basis for determining liabilities of directors while reviewing corporate criminal liability and this is in line with the English Common law attribution principles under the doctrine of the alter ego.

\section{COLUSION}

While still grappling with the nature and applicability of corporate criminal liability the law has also moved to an avenue that qualifies mens rea further by highlighting 'wilful blindness' as both a form of intention and 'state of mind' of natural persons and companies. Wilful blindness falls under the criminal law doctrine of conscious avoidance and in United States v Goffer ${ }^{97}$ the court concluded that wilful blindness is enough as a mens rea to convict for wilful misconduct. But the subjective test for wilful blindness in the US was set in Global Tech Appliances Inc. v SEB S.A ${ }^{98}$ where the court set a standard of two component parts. First the defendant must 'subjectively believe that there is a high probability that a fact exists" ${ }^{99}$ and secondly he must have taken deliberate steps and actions 'to avoid learning of that fact'. ${ }^{100}$ Importantly, the court concluded that a defendant who meets these conditions is as culpable as those who have actual knowledge. In the UK courts have also accepted wilful blindness as a form of mens rea in determining culpability; in Regina v Sleep ${ }^{101}$ the court referred to instances where the defendant 'wilfully shuts his eyes to that fact' in determining the scope of his intention in committing a crime of possessing stolen goods. In two other English cases; Bosley v Davies ${ }^{102}$ and Redgate v Haynes; ${ }^{103}$ the courts suggested that actual knowledge is even unnecessary where it could be shown

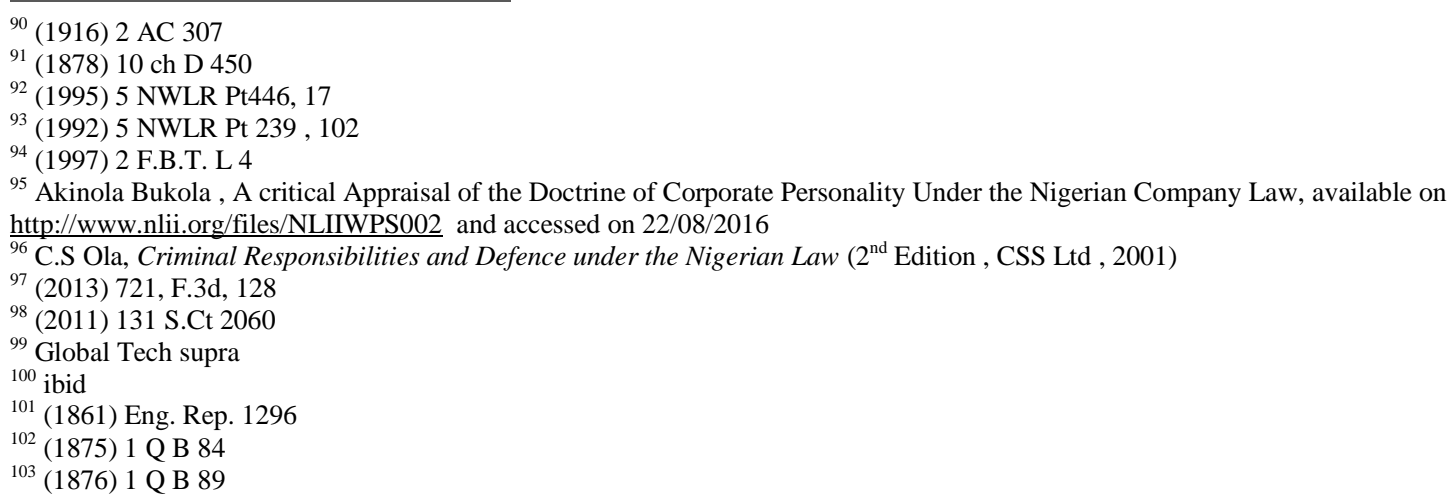


that a defendant wilfully blinded himself to facts and refused to ascertain facts. Hence in looking at acts of 'directing minds and will' we must be conscious that even where there are no confirmation of actual intentions, the court can look at avenues where the natural persons driving a company were 'wilfully blind'.

It is clear that when we are evaluating corporate criminal liability in Nigeria; we must focus on the doctrine of alter ego which is the adopted approach to determining actual intentions and corporate mens rea. Likewise there is a need to link up the 'sub-layer' of wilful blindness as a form of assessing the actual intentions of those that are the 'directing minds and will' of the company as contemplated in the Leanard's Carrying ${ }^{104}$ case. This will clearly raise the bar due to the complex nature of determination of wilful blindness and the penchant of English and US courts to only apply it to natural persons; whose state of mind has always been the bedrock of criminal prosecution over the centuries. Therefore it will be difficult to determine the state of mind of a non-natural juristic person and even go deeper into areas where it acts wilfully blind to facts as to create an alternative mens rea as envisaged by the doctrine. But the alter ego principles have open up an avenue to hold juristic persons to the same standards in criminal law as envisaged by the courts and law makers in outlining the borders of corporate criminal liability. This will allow us extend the determination of corporate criminal behaviour to the more complex requirements of wilful blindness.

\section{REFERENCES}

[1]. Leigh, "The Alter Ego of a Company" (1965) 28 M.L.R. 584 at 585.

[2]. P. Watts, "The Company's Alter Ego-an Impostor in Private Law" (2000) 116 L.Q.R. 525. The argument is developed further in P. Watts, "Imputed Knowledge in Restitutionary Claims-Rationales and Rations", in S. Degeling and J. Edelman, Unjust Enrichment in Commercial Law (Sydney: Thomson Reuters, 2008) at Ch.21.

[3]. P. Watts, "Auditors and Corrupt Clients" (2009) 125 L.Q.R. 38 at 41

[4]. Pamela H. Bucy, Why Punish?, Trends in Corporate Criminal Prosecutions(1988)44 Am. CRIM. L. REV. 1287,

[5]. Patricia S. Abril \& Ann Morales Olazbal, The Locus of Corporate Scienter,(2006) COLuM. Bus. L. REV. 81 ,

[6]. Eli Lederman, Models for Imposing Corporate Criminal Liability: From Adaptation and Imitation Toward Aggregation and the Search for Self-Identity (2000) 4 BuFF. CRIm. L. REV. 641, 666

[7]. R.S welsh, The Criminal Liability of Corporations (1946) 62 Law Q. Rev 346

[8]. Erhaze, S., \& Momodu, D. (2015). Corporate Criminal Liability: Call for a New Legal Regime in Nigeria. Journal of Law and Criminal Justice, 3(2), 63-72.

[9]. Pinto and Evans, Corporate Criminal Liability ( $2^{\text {nd }}$ Edition, Sweet and Maxwell , 2008) pg 77-78

[10]. J. Olakunle Orojo ,Company Law and Practice in Nigeria , ( ${ }^{\text {th }}$ Edition , LexisNexis 2013) pg 88

[11]. Akinola Bukola , A critical Appraisal of the Doctrine of Corporate Personality Under the Nigerian Company Law, available on http://www.nlii.org/files/NLIIWPS002 and accessed on 22/08/2016

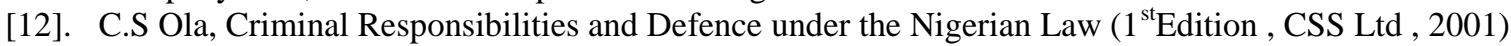

